\title{
Analisis Perencanaan Strategis Sistem Informasi Pada Manies Group Madiun dengan Pemodelan Ward dan Peppard Untuk Meningkatkan Pelayanan Pelanggan
}

\author{
Sri Anardani*, Andi Rahman Putera \\ a,b Program Studi Teknik Informatika \\ Universitas PGRI Madiun \\ Naskah Diterima : 12 Juli 2018; Diterima Publikasi : 30 Oktober 2018
}

DOI : $10.21456 /$ vol8iss2pp211-217

\begin{abstract}
Manies Group is a company engaged in the sale of fashion that has been known by the people of the City of Madiun since 1971. Business competition is getting higher with the construction of several Mall and Department Stores. One strategy to deal with such competition is through information technology and information systems. For this reason, it is necessary to analyze the information system strategic planning for Manies Group. The purpose of this study is to identify data needs to develop information systems and information technology. The planning analysis methodology uses the framework of John Ward and Joe Peppard. The analysis results are mapped using portfolio designs using McFarlan's Strategic Grid. The final result of this research is a document on the IS / IT strategic plan that supports the process of designing and building information systems for Manies Group.
\end{abstract}

Keywords : Information Systems; Strategic Planning; Modeling of Ward and Peppard; Strategic Grid McFarlan.

\begin{abstract}
Abstrak
Manies Group adalah perusahaan yang bergerak dibidang penjualan fashion yang sudah dikenal oleh masyarakat Kota Madiun sejak tahun 1971. Persaingan usaha semakin tinggi dengan adanya pembangunan beberapa Mall dan Department Store. Salah satu strategi menghadapi persaingan tersebut adalah melalui teknologi informasi dan sistem informasi. Untuk itu perlu adanya analisa perencanaan strategis sistem informasi bagi Manies Group. Tujuan dari penelitian ini adalah mengidentifikasi kebutuhan data untuk mengembangkan sistem informasi dan teknologi informasi. Metodologi analisis perencanaan menggunakan kerangka kerja Ward dan Peppard. Hasil analisis dipetakan menggunakan rancangan portofolio menggunakan Strategic Grid McFarlan. Hasil akhir dari penelitian ini adalah sebuah dokumen rencana strategis SI/TI yang mendukung proses perancangan dan pembangunan sistem informasi Manies Group.
\end{abstract}

Kata kunci :Sistem Informasi; Perencanaan Strategis; Pemodelan Ward dan Peppard;Strategic Grid McFarlan

\section{Pendahuluan}

Manies Group Madiun adalah perusahaan yang bergerak dibidang penjualan fashion, tas dan sepatu di Kota Madiun. Saat ini Manies Group Madiun telah memiliki 4 toko dengan lokasi tersebar di sekitar Kota Madiun. Toko Manies Group yang berdiri pada tahun 1971 sudah dikenal dari generasi ke generasi. Persaingan usaha penjualan fashion di Kota Madiun semakin hari semakin ketat. Hal ini disebabkan munculnya beberapa Mall dan Department Store.

Menghadapi persaingan tersebut Manies Group harus berbenah pada pengelolaan manajemen. Saat ini aktivitas pemasaran produk masih dilakukan dengan cara konvensional, yaitu dengan cara pelanggan

\footnotetext{
*) Penulis korespondensi: anardani@unipma.ac.id
}

datang ke toko kemudian pelanggan tersebut memberikan informasi kepada pelanggan lain. Mempertahankan pelanggan lama dan menarik perhatian pelanggan baru merupakan salah satu strategi yang diperlukan untuk bisa bertahan ditengah persaingan bisnis.

Seiring dengan perkembangan teknologi informasi maka perlu diterapkan strategi yang memanfaatkan teknologi informasi. Pengembangan sistem informasi bagi organisasi atau perusahaan yang didukung dengan teknologi informasi bisa menjadi salah satu strategi untuk meningkatkan daya saing (Septiana, 2017). Agar tujuan Manies Group untuk meningkatkan pelanggan dapat tercapai maka perlu diterapkan sistem informasi yang didukung oleh 
teknologi informasi untuk menyimpan dan mengelola data pelanggan. Perencanaan pembangunan sistem informasi harus disesuaikan dengan strategi organisasi Manies Group sehingga Sistem Informasi yang dibangun dapat meningkatkan nilai organisasi. Perencanaan pembangunan SI/TI yang tepat dapat mendukung dan meningkatkan keunggulan kompetitif organisasi dengan mengubah cara berbisnis (Irfan dan Abdi, 2016).

Penerapan Sistem Informasi yang didukung Teknologi informasi dalam mengelola proses bisnis belum dijalankan di Manies Group . Salah satu akibat yang dirasakan adalah pengelolaan data pelanggan hingga kegiatan operasional yang berhubungan dengan pelanggan menjadi tidak efisien sehingga berdampak pada resiko kehilangan data pelanggan. Oleh karena itu dibutuhkan sebuah perencanaan strategis untuk membangun Sistem Informasi dan Teknologi Informasi berdasarkan kebutuhan Manies Group untuk mendukung pelayanan terhadap pelanggan.

Secara garis besar penelitian ini bertujuan untuk menganalisa membuat perencanaan strategis sistem informasi dan teknologi informasi dengan menggunakan pemodelan Ward dan Peppard. Hasil perencanaan ini adalah sebuah dokumen rekomendasi bagi Manies Group untuk menentukan prioritas pengembangan Sistem Informasi dan Teknologi Informasi yang dapat mendukung keberlangsungan bisnis Manies Group ke depan.

\section{Kerangka Teori}

\subsection{Perencanaan Strategis Sistem Informasi dan Teknologi Informasi}

Perencanaan Strategis Sistem Informasi merupakan proses identifikasi portofolio aplikasi berbasis komputer yang selaras dengan strategi perusahaan yang bertujuan untuk menciptakan keuntungan dan mewujudkan tujuan bisnisnya (IssaSalwe et al., 2011). Kegiatan perencanaan strategis sistem informasi bertujuan untuk mengenali kebutuhan sistem informasi suatu organisasi hingga organisasi mampu mendapatkan nilai tambah untuk memperoleh keuntungan bisnis.

Perencanaan Strategis SI/TI adalah proses memilih langkah-langkah strategis penggunaan SI/TI yang dapat memberikan pengaruh bagi kinerja bisnis (Wijaya dan Manongga, 2012). Perencanaan strategis SI/TI memberikan informasi identifikasi alat, teknik dan kerangka kerja bagi manajemen untuk menyelaraskan dengan strategi bisnis organisasi.

Proses analisa perencanaan strategi SI/TI tidak hanya fokus pada teknologi SI/TI saja namun harus mempertimbangkan keseluruhan aspek yaitu menganalisa persoalan bisnis dan perubahan lingkungan (Pipin et al., 2011)

\subsection{Pemodelan Ward dan Peppard}

Pemodelan Perencanaan SI/TI Ward dan Peppard terdiri atas 2 tahap yaitu: Tahapan analisis input dan tahap analisis output. Tahapan analisis input terdiri atas analisis lingkungan bisnis internal dan eksternal serta analisis lingkungkungan SI/TI internal dan eksternal. Tahapan analisis output terdiri atas strategi bisnis, strategi SI/TI dan strategi manajemen SI/TI.

Secara garis besar tahap-tahap proses perencanaan strategis dengan menggunakan pemodelan Ward dan Peppard dapat diperlihatkan pada Gambar 1 (Ward dan Peppard, 2002).

Proses analisa yang dilakukan dengan kerangka Ward dan Peppard terdiri dari beberapa kegiatan dengan tahap pertama adalah analisis lingkungan bisnis eksternal dan internal, yaitu identifikasi kondisi ekonomi , kondisi lingkungan industri, persaingan bisnis, strategi bisnis yang sedang dijalankan, dan sumber daya perusahaan.

Tahap kedua meliputi analisa lingkungan SI/TI eksternal dan internal, yaitu identifikasi trend teknologi, infrastruktur teknologi perusahaan serta perspektif SI/TI sekarang. Tahap ini juga dapat menambahkan kegiatan analisa kondisi aplikasi SI/TI yang sudah dimiliki.

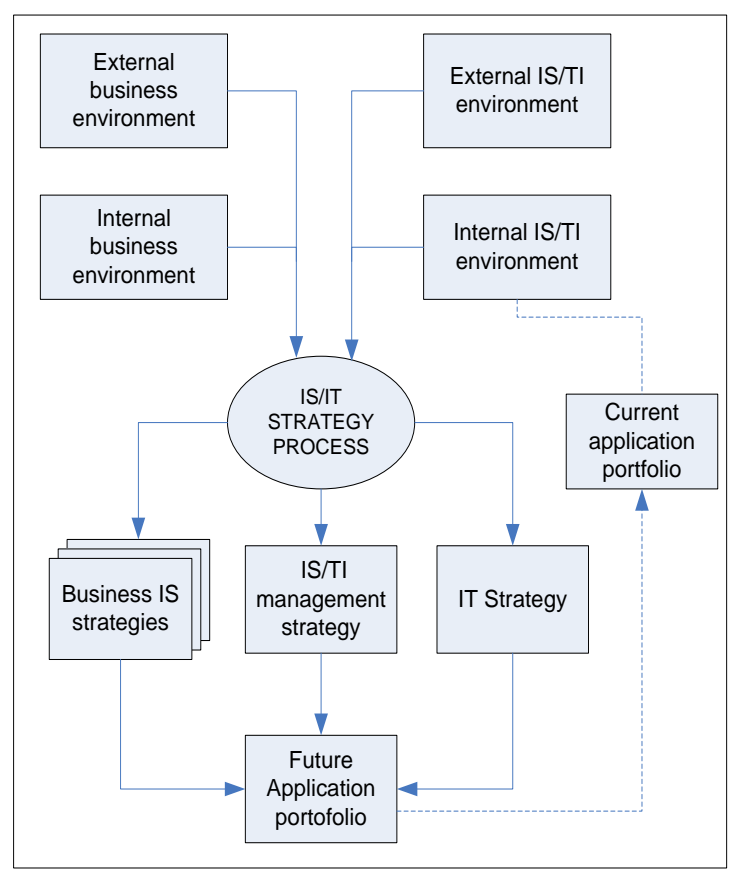

Gambar 1. IS/TI Strategic Model Ward dan Peppard.

Setelah menganalisa lingkungan SI/TI maka berikutnya adalah tahap analisa Proses Strategi SI/TI yaitu dengan mengidentifikasi kandidat sistem informasi yang bisa mendukung proses bisnis. Kegiatan kedua adalah identifikasi strategi manajemen berupa elemen-elemen kebijakan perusahaan yang mendukung SI/TI. Kegiatan terakhir dari proses Analisa strategis SI/TI adalah menentukan strategi teknologi informasi yaitu identifikasi 
teknologi dan sumber daya yang mampu mendukung pengembangan Sistem Informasi.

Langkah terakhir dari pemodelan Ward dan Peppard adalah melakukan pemetaan kandidat system informasi dan teknologi informasi dengan menggunakan Strategic Grid Mc.Farlan. Hasil pemetaan menggambarkan kebutuhan SI/TI di masa yang akan datang.

\subsection{Analisa Value Chain}

Dalam rangka proses analisa proses bisnis internal maka diperlukan metode Value Chain. Metode analisa value chain adalah metode yang digunakan untuk menjabarkan aktivitas proses bisnis yang diklasifikasikan kedalam dua aktivitas yaitu aktivitas utama dan aktivitas pendukung, dimana hasil analisis ini akan digunakan untuk identifikasi kebutuhan SI/TI dari organisasi (Wijaya dan Manongga, 2012).

Konsep analisa value chain dijabarkan oleh Michael Porter yang menyatakan bahwa setiap perusahaan memiliki beberapa aktivitas yang dilakukan untuk merancang, memproduksi dan memasarkan produk atau jasa. Seluruh aktivitas perusahaan tersebut dapat diwakili dengan menggunakan diagram value chain (Ward dan Peppard, 2002)

\subsection{Analisa SWOT}

Pada langkah-langkah kerja Ward dan Peppard diperlukan proses analisa proses bisnis internal dan eksternal, maka diperlukan analisa SWOT. Metode Analisa SWOT digunakan untuk mengidentifikasi kekuatan dan kelemahan sumber daya organisasi, peluang sekaligus ancaman bagi organisasi (Septiana, 2017). Dengan mengetahui kelemahan dan kekuatan organisasi serta peluang dan ancaman maka dapat diketahui posisi bisnis organisasi sehingga strategi yang dipilih akan selaras dengan kondisi organisasi.

Analisa SWOT mampu mendeteksi kekuatan dan kelemahan sehingga perusahaan dapat membangun strategi untuk kompetisi. Perusahaan juga mampu menangkap kesempatan dan mempertahankan bisnis dari ancaman-ancaman.

\subsection{Analisa PEST}

Pada tahap awal perencanaan strategis SI/TI di kerangka Ward dan Peppard (2002), faktor-faktor lingkungan eksternal menjadi bahan yang harus dipertimbangkan. Metode PEST (Politik, Ekonomi, Sosial dan Teknologi) merupakan pendekatan yang digunakan untuk menganalisa pengaruh lingkungan eksternal bagi organisasi (Ward dan Peppard, 2002).

Mengantisipasi lingkungan eksternal sangat penting untuk dilakukan karena kecepatan perubahan lingkungan sangat mempengaruhi persaingan bisnis. Pengaruh lingkungan yang harus dihadapi oleh organisasi menurut metode PEST terdiri atas 4 aspek yaitu Politik, Ekonomi, Sosial dan Teknologi. Aspek politik, menganalisa peraturan-paeraturan pemerintah, kebijakan pemerintah, undang-undang yang berlaku dan aturan-aturan formal lainnya. Aspek ekonomi, menganalisa kondisi ekonomi untuk saat ini dan prediksi di masa yang akan datang yang berpotensi mempengaruhi proses bisnis organisasi. Aspek sosial, menganalisa penilaian masyarakat terhadap organisasi yang bisa mempengaruhi proses bisnis organisasi. Aspek teknologi, menganalisa perubahan teknologi yang dapat memberikan peluang bagi organisasi sekaligus sebagai ancaman

\subsection{Strategic Grid Mc Farlan}

Setelah tahap analisa internal dan eksternal diselesaikan pada tahapan Ward dan Peppard adalah membuat identifikasi portofolio aplikasi dimasa depan. Untuk identifikasi tersebut dibutuhkan metode pemetaan aplikasi yaitu Strategic Grid McFarlan.

Metode pemetaan kebutuhan SI/TI Strategic Grid McFarlan dikelompokkan ke dalam 4 kuadran yaitu kuadran support, kuadran operational, kuadran high potential dan kuadran Strategic (Kiki, 2016). Mc.Farlan Strategic Grid memetakan kebutuhan SI/TI di masa datang sehingga dapat diketahui dukungan SI/TI bagi perusahaan (Agustono et al, 2013).

Melalui pemetaan Strategic Grid Mc.Farlan dapat mempermudah pihak manajemen organisasi untuk menentukan posisi SI/TI agar selaras dengan proses bisnis organisasi di masa datang.

\section{Metode}

Penelitian perencanaan strategis SI/TI ini menggunakan kerangka kerja Ward dan Peppard Model. Kerangka kerja ini sebagai pedoman untuk melaksanakan proses Analisa perencanaan SI/TI Adapun kerangka kerja penelitian dapat dilihat pada Gambar 2.

Pemodelan Ward dan Peppard untuk proses perencanaan strategis SI/TI diawali dengan Analisa Lingkungan Bisnis yaitu menganalisa mekanisme manajemen, tanggung jawab tiap bagian, sumber daya dan budaya di lingkungan bisnis. Kebutuhan data berikutnya adalah kondisi SI/TI dengan melakukan Analisa Lingkungan SI/TI yaitu berupa analisa trend teknologi dan penerapan teknologi saat ini yang mendukung pelayanan kepada pelanggan.

Analisa proses bisnis dan kondisi SI/TI telah di identifikasi, maka langkah berikutnya adalah Identifikasi Strategi Bisnis dengan menganalisa kebutuhan bisnis melalui kekuatan, kelemahan, kesempatan dan ancaman bagi perusahaan. Berdasarkan strategi bisnis internal maka langkah berikutnya adalah melakukan pemetaan SI/TI yaitu sebuah kegiatan menentukan aplikasi yang dibutuhkan dan aplikasi potensial bagi perusahaan di masa datang yang bisa meningkatkan mutu layanan terhadap pelanggan. 
Teknik pengumpulan data yang digunakan pada proses penelitian ini adalah: melakukan observasi, dengan berkunjung ke 4 cabang toko Manies Group Madiun untuk mengamati kegiatan proses bisnis secara langsung. Langkah berikutnya wawancara dengan pimpinan Manies Group dan tim manajemen yang yang mengetahui kondisi bisnis Manies Group saat ini.

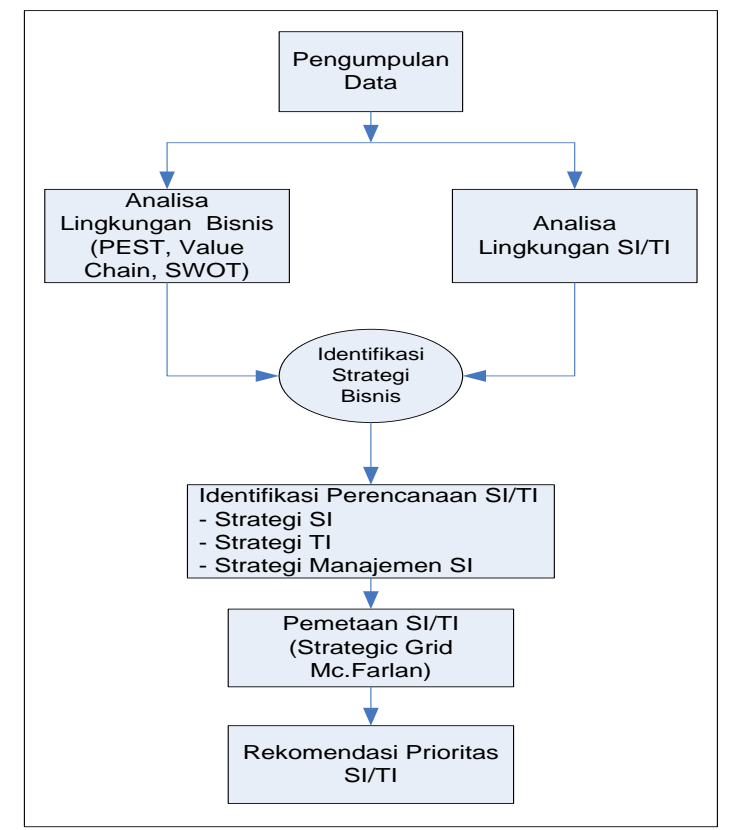

Gambar 2. Metodologi penelitian

Untuk melengkapi proses penelitian dilakukan juga kegiatan Studi Kepustakaan, menggunakan referensi-referensi yang berkaitan dengan penelitian berupa jurnal ilmiah, sumber buku dan penelitianpenelitian terdahulu terkait perencanaan strattegis.

Langkah berikutnya setelah pengumpulan data, sesuai kerangka Ward dan Peppard adalah melakukan analisis proses bisnis internal dan eksternal. Untuk analisis proses bisnis internal dan eksternal menggunakan metode Value Chain, SWOT dan PEST. Kemudian untuk analisa lingkungan SI/TI dilakukan proses analisa kebutuhan infrastruktur teknologi dan kondisi sistem informasi.

Proses terakhir yang dilakukan adalah identifikasi pemetaan kebutuhan SI/TI menggunakan Strategic Mc Farlan. Dalam pemetaan ini berisi rekomendasi prioritas SI/TI yang dapat dikembangkan di masa yang akan datang.

SI/TI yang berhasil di identifikasi dapat menjadi alat bantu bagi perusahaan untuk meningkatkan mutu pelayanan pelanggan. SI/TI yang dibangun dapat memberikan informasi yang dibutuhkan pelanggan seperti informasi detail produk, informasi harga, informasi promosi dan pelanggan dapat menyampaikan keluhan dengan cepat dan tepat. Pelayanan yang cepat dan tepat sangat diharapkan oleh pelanggan. Apabila kebutuhan data yang diminta oleh pelanggan dapat terpenuhi dengan cepat dan tepat maka pelanggan akan merasa puas.

\section{Hasil dan Pembahasan}

Berdasakan hasil wawancara didapatkan visi Manies Group Madiun adalah menjadi Toko Pakaian dan Aksesoris yang berkualitas, trendy dan terpercaya. Sedangkan misinya adalah :

a. Menjual Produk Fashion yang bermutu dengan harga terjangkau.

b. Memberikan pelayanan yang optimal kepada pelanggan.

c. Membangun citra positif dalam hubungan yang tulus dengan stakeholder.

Dari Visi dan Misi dapat digambarkan bahwa Manies Group sangat memperhatikan pelayanan kepada pelanggan, untuk menjaga kualitas bisnisnya. Untuk menjaga pelayanan kepada pelanggan diperlukan beberapa strategi, diantaranya adalah mengadopsi SI/TI untuk membantu proses bisnis.

\subsection{Analisis Lingkungan Bisnis}

Sesuai dengan kerangka kerja Ward dan Peppard maka langkah selanjutnya adalah menganalisa lingkungan bisnis, yaitu lingkungan internal dan eksternal. Teknik analisa yang menggunakan beberapa metode yaitu:

\section{Analisa Value Chain}

Analisa bisnis lingkungan internal menggunakan Value Chain, dikelompokkan berdasarkan aktivitas utama dan aktivitas pendukung. Pengelompokkan aktivitas bisnis Manies Group saat ini dapat digambarkan dengan diagram Value Chain sebagai berikut:

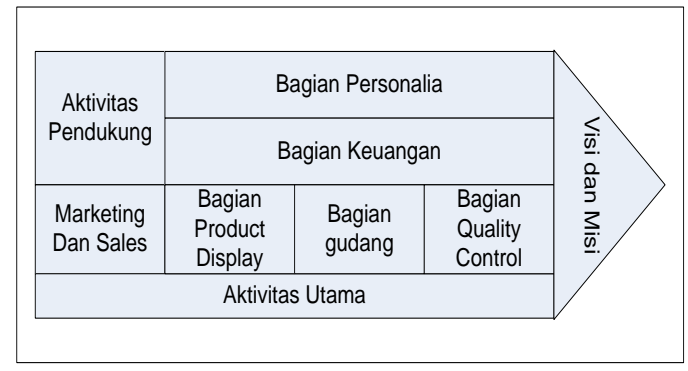

Gambar 3. Diagram Value Chain Manies Group

Aktivitas utama Manies Group adalah sebagai berikut:

a. Marketing dan Sales: mengelola outlet, iklan dan brand ambassador.

b. Bagian Product Display: menangani product packaging.

c. Bagian Gudang: mengelola penyimpanan dan pengadaan barang.

d. Bagian Quality Control: memastikan kualitas produk.

Aktivitas pendukung Manies Group adalah seperti berikut: 
a. Bagian Personalia: menangani perekrutan dan pelatihan yang dibutuhkan karyawan.

b. Bagian Keuangan: menengelola laporan keuangan, penggajian karyawan.

\section{Analisa PEST}

Faktor-faktor eksternal yang mempengaruhi kondisi bisnis Manies Group saat ini dijabarkan dengan metode analisa PEST seperti berikut ini:

a. Politik

Kebijkan pemerintah Kota Madiun yang mencanangkan Madiun sebagai kota GADIS (Perdagangan dan Industri) merupakan kesempatan bagi Manies Group untuk terus mengembangkan usahanya. Kebijakan tersebut juga menjadi kendala bagi Manies Group karena pemerintah Kota Madiun telah memberikan ijin pendirian 4 mall dan Department Store yang akan menjadi pesaing bagi Manies Group.

b. Ekonomi

Sebagai Kota perdagangan dan industri Kota Madiun memiliki potensi industri Kereta Api Nasional (PT. INKA) dan beberapa pabrik gula. Potensi industry ini mampu meningkatkan perekonomian masyarakat Kota Madiun. Kebijkan pemerintah untuk mendirikan Perguruan Tinggi Negeri di Kota Madiun juga mampu meningkatkan perekonomian masyarakat. Hal ini juga berdampak pada Manies Group karena meningkatnya ekonomi maka daya beli masyarakat juga meningkat.

Tabel 1. Analisa SWOT

\begin{tabular}{|c|c|}
\hline Kekuatan & Ancaman \\
\hline $\begin{array}{ll}\text { a. } & \text { Berdiri sejak tahun } \\
& \text { 1971 sehingga sangat } \\
& \text { dikenal oleh } \\
& \text { masyarakat Kota } \\
& \text { Madiun dan } \\
\text { sekitarnya. } \\
\text { b. } \\
\text { Brand Manies dikenal } \\
\text { sebagai toko fashion } \\
\text { dan aksesoris yang } \\
\text { berkualitas. } \\
\text { c. } \\
\text { Menyediakan } \\
\text { kebutuhan fashion } \\
\text { untuk segala ukuran } \\
\text { hingga ukuran bigsize }\end{array}$ & $\begin{array}{ll}\text { a. } & \begin{array}{l}\text { Berdirinya } 3 \\
\text { mall besar }\end{array} \\
\text { dengan brand } \\
\text { fashion yang } \\
\text { sudah dikenal } \\
\text { secara nasional. } \\
\text { b. } \\
\text { Pertumbuhan } \\
\text { toko online yang } \\
\text { pesat. }\end{array}$ \\
\hline Kelemahan & Peluang \\
\hline $\begin{array}{ll}\text { a. } & \text { Menjalankan proses } \\
\text { pemasaran secara } \\
\text { konvensional. } \\
\text { b. Sistem promosi hanya } \\
\text { melalui radio daerah. }\end{array}$ & $\begin{array}{ll}\text { a. } & \text { Brand Toko } \\
\text { Manies yang } \\
\text { sudah melekat } \\
\text { dihati } \\
\text { masyarakat Kota } \\
\text { Madiun secara } \\
\text { turun menurun }\end{array}$ \\
\hline
\end{tabular}

c. Sosial

Rata-rata penduduk Kota Madiun adalah Pegawai Negeri Sipil dan karyawan swasta dengan tingkat Pendidikan Tinggi yang terus bertambah tiap tahunnya. Menurut data statistik kenaikan tiap tahun sebesar 18\%. Kondisi sosial masyarakat Kota Madiun ini bisa jadi bahan pertimbangkan untuk menentukan trend fashion yang tepat dipasarkan di Kota Madiun.

d. Teknologi

Kemajuan teknologi yang terus melaju terutama teknologi informasi memberikan dampak bagi Manies Group. Toko-toko fashion yang menggunakan konsep online terus menjamur dan menjadi pesaing yang tidak bisa diabaikan.

3. Analisa SWOT

Untuk mengidentifikasi kekuatan, kelemahan, peluang dan ancaman proses bisnis Manies Group maka diperlukan matrik SWOT (Strenght, Weaknesses, Opportunities, Threats). Hasil analisis SWOT diberikan pada Tabel 1.

\subsection{Analisis Lingkungan SI/TI}

Tahap analisa lingkungan SI/TI bertugas mengidentifikasi kondisi SI/TI Manies Group saat ini. Ada 2 tahap analisa yaitu:

a. Analisa Lingkungan SI/TI Internal

Saat ini secara umum Manies Group belum menerapkan SI/TI walaupun hanya sekedar konsep. Seluruh penyelenggaraan proses bisnis belum melibatkan SI/TI. Seluruh pengolahan data proses bisnis menggunakan cara konvensional.

b. Analisa Lingkungan SI/TI Eksternal

Perkembangan SI/TI saat ini sangat pesat, Di Kota Madiun beberapa penjual memanfaatkan media social untuk memasarkan produknya. Belanja Online menggunakan teknologi website juga tumbuh pesat.

\subsection{Identifikasi Perencanaan SI/TI}

Langkah-langkah analisis internal dan eksternal telah dilakukan, maka sesuai kerangka Ward dan Peppard maka langkah selanjutnya adalah identifikasi perencanaan SI/TI. Adapun dasar dari perencanaan Kebutuhan SI/TI adalah visi dan misi dari Manies Group. Analisa kebutuhan SI/TI yang mendukung Visi dan Misi Manies Group diberikan pada Tabel 2.

Berdasarkan Tabel 2, maka usulan kebutuhan Sistem Informasi yang teridentifikasi adalah sebagai berikut:

a. Sistem Informasi Keuangan

Dibutuhkan untuk mengelola keuangan Manies Group.

b. Sistem Informasi Inventory

Sistem ini dibutuhkan untuk mengelola data gudang dan data stok barang

c. Sistem Informasi SDM

Dibutuhkan untuk mengelola data penilaian kinerja SDM dan riwayat selama bekerja. 
d. Website Pemasaran

Sistem ini dibutuhkan untuk meningkatkan pelayanan penjualan kepada pelanggan.

e. Aplikasi Kasir

Sistem ini dibutuhkan untuk meningkatkan pelayanan proses pembayaran kepada pelanggan.

Sedangkan untuk usulan teknologi informasi yang telah teridentifikasi adalah:

a. Pembangunan Jaringan Komputer

b. Menambah bandwith akses koneksi internet.

Tabel 2. Matrik analisa kebutuhan SI/TI $\begin{array}{cc}\text { Strategi } & \text { Strategi } \\ \text { SI } & \text { TI }\end{array}$

Visi Misi

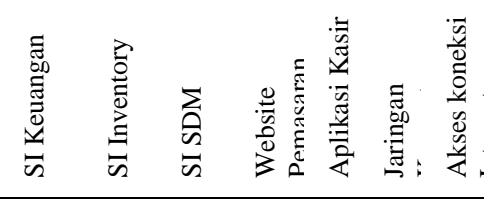

\begin{tabular}{|c|c|c|c|c|c|c|c|}
\hline $\begin{array}{l}\text { Visi } \\
\text { Menjadi Toko } \\
\text { Pakaian dan } \\
\text { Aksesoris yang } \\
\text { berkualitas, trendy } \\
\text { dan terpercaya }\end{array}$ & $\sqrt{ }$ & $\sqrt{ }$ & $\sqrt{ }$ & $\sqrt{ }$ & $\sqrt{ }$ & $\sqrt{ }$ & $\sqrt{ }$ \\
\hline $\begin{array}{l}\text { Misi } \\
\text { Menjual Produk } \\
\text { Fashion yang } \\
\text { bermutu dengan } \\
\text { harga terjangkau }\end{array}$ & & $\sqrt{ }$ & & $\sqrt{ }$ & $\sqrt{ }$ & $\sqrt{ }$ & $\sqrt{ }$ \\
\hline $\begin{array}{l}\text { Memberikan } \\
\text { pelayanan yang } \\
\text { optimal kepada } \\
\text { pelanggan }\end{array}$ & & & & $\sqrt{ }$ & $\sqrt{ }$ & $\sqrt{ }$ & $\sqrt{ }$ \\
\hline $\begin{array}{l}\text { Membangun citra } \\
\text { positif dalam } \\
\text { hubungan yang } \\
\text { tulus dengan } \\
\text { stakeholder }\end{array}$ & $\sqrt{ }$ & $\sqrt{ }$ & $\sqrt{ }$ & $\sqrt{ }$ & $\sqrt{ }$ & $\sqrt{ }$ & $\sqrt{ }$ \\
\hline
\end{tabular}

\subsection{Identifikasi Pemetaan Strategic Grid Mc.Farlan}

Berdasarkan hasil pemaparan matrik analisa kebutuhan SI/TI maka pemetaan kebutuhan SI/TI Manies Group di masa datang digolongkan kedalam 4 kuadran Strategic Grid Mc. Farlan yaitu yang pertama Kuadran Strategic, merupakan kuadran untuk sistem atau aplikasi yang berfungsi untuk memudahkan proses bisnis dan transaksi sehingga berpengaruh pada kesuksesan Manies Group dimasa datang. Sistem informasi yang masuk pada kuadran ini adalah Website Pemasaran, Aplikasi Kasir, pembangunan jaringan komputer dan akses internet.

Kuadran kedua adalah Key Operational, merupakan kuadran yang digunakan untuk mendeteksi sistem informasi yang dibutuhkan untuk mengelola proses bisnis namun tidak secara langsung memberikan keuntungan kompetitif. Sistem yang masuk adalah sistem informasi keuangan.

Kuadran High Potential, sistem yang memiliki nilai kompetitif namun tidak memberikan dampak saat ini. Sistem yang masuk kelompok ini Sistem informasi Inventory.

Kuadran Support, sistem yang berfungsi sebagai pendukung proses bisnis namun tidak berpengaruh pada kelangsungan bisnis, sistem kelompok ini adalah Sistem informasi SDM.

Berdasarkan hasil penjabaran dari Tabel 2, maka tersusun aplikasi portofolio Manies Group dengan prioritas yang berpedoman pada Strategic Gird Mc. Farlan seperti diberikan pada Gambar 4.

\begin{tabular}{|c|c|}
\hline Strategic & High Potential \\
\hline Website Pemasaran & \\
Aplikasi Kasir & $\begin{array}{c}\text { Sistem Informasi } \\
\text { Inventory }\end{array}$ \\
$\begin{array}{c}\text { Pembangunan Jaringan } \\
\text { Komputer }\end{array}$ \\
Akses koneksi internet & \\
\hline Sistem Informasi \\
Keuangan & Sistem Informasi SDM \\
\hline Key Operational & Support \\
\hline
\end{tabular}

Gambar 4. Aplikasi Portofolio Strategic Mc.Farlan Manies Group

\section{Kesimpulan}

Pemodelan Ward dan Peppard menyusun rencana strategis sistem informasi dengan mengidentifikasi lingkungan bisnis, lingkungan IT kemudian menyelaraskan dengan strategi bisnis. Hasil identifikasi SI/TI dipetakan menggunakan Strategic Grid Mc.Farlan.

Hasil pemetaan dibagi menjadi 4 kuadran yaitu posisi kuadran strategic dengan aplikasi website pemasaran aplikasi kasir, pembangunan jaringan komputer dan akses internet. Kuadran Key Operational berisi sistem informasi keuangan. Posisi Kuadran High Potential ditempati sistem informasi inventory. Kuadran Support adalah sistem informasi SDM. Kandidat-kandidat aplikasi ini akan dapat membantu proses bisnis di Manies Group lebih cepat dan tepat sehingga bisa meningkatkan proses pelayanan kepada pelanggan.

\section{Daftar Pustaka}

Agustono, H., Suyanto, M., Sudarmawan, 2013. Perencanaan strategis sistem informasi stmik cahaya surya kediri. Citec Journal 1(1), 15-24.

Irfan, N.A., Abdi, D., 2016. Perencanaan strategis sistem informasi dan teknologi informasi si/ti pendidik dan tenaga kependidikan (studi kasus: pada disdikbudpora metro). Jurnal TIM Darmajaya 2(1),41-5.

Issa-salwe, A.M., Sharif, L., Ahmed, M., 2011. Strategic information systems planning as the centre of information systems strategies. 
International Journal of Research and Reviews in Computer Science 2(1), 156-162.

Kiki, O., 2016. Perencanaan strategis sistem informasi sumber daya manusia pada STMIK Banjarbaru. Indonesian Journal on Networking and Security 5(2), 1-6.

Pipin, W., Mustafid, M., Adian, F.R,, 2011. Perencanaan strategis sistem informasi pada institusi pendidikan tinggi menggunakan analisis critical success factors. Jurnal Sistem Informasi Bisnis 1(2), 87-93.

Septiana, Y., 2017. Perencanaan strategis sistem informasi dengan pendekatan ward dan peppard model (Studi Kasus: Klinik INTI Garut). Jurnal Wawasan Ilmiah 8 (1), 8-24.

Ward, J, Peppard, J., 2002. Strategic Planning for Information System Third Editio. John Wiley \& Sons Ltd, Bedfordshire, UK.

Wijaya, A.F., Manongga, D., 2012. Information systems strategic planning to increase competitive advantage of higher education using be vissta planning methodology (case study: SWCU Salatiga). International Journal of Organization Innovation 5(2), 68-82. 